\title{
THE NETHERLANDS: THE ZUYDER ZEE PROJECT
}

\author{
MARCEL J.F. STIVE and RONALD E. WATERMAN \\ Netherlands Centre for Coastal Research \\ Delft University of Technology \\ Faculty of Civil Engineering \\ P.O. Box 5048, 2600 GA Delft, The Netherlands
}

\section{Introduction}

The closing off and the partial reclamation of the Zuyder Zee has resulted in the gain of 166,000 hectares of new land (Figure 1). This new land appears to lend itself for agriculture, urban development, recreation and nature conservation.

As early as in 1667 , the first idea for reclamation was published by Hendric Stevin. However, the idea was conceived prematurely: it could not be realised technologically. In the 19 th century, the idea was given serious consideration, new plans were constantly made, but never carried out. Not until 1891 a plan, drawn up by Comelis Lely, was published which turned out to be feasible. It was a plan of great simplicity: the closure of the Zuyder Zee in the 'neck' with a $30 \mathrm{~km}$ long dam. The enclosed part, fed with fresh water from the river IJssel and by rainfall, would subsequently turn fresh. Within this area, from then on to be called Ijsselmeer (Lake Yssel), five polders were to be constructed for agricultural use, with a joint surface of 220,000 hectares. The remaining part was to be a fresh water basin, of great importance for a country having to cope with salinization problems. As a result of the closing off, the coastline of the Netherlands was reduced by nearly $300 \mathrm{~km}$, which made it much easier to defend.

A plan of great simplicity, but a large-scale and expensive operation, and the realisation would span a very long period of time. As so often in history, coincidence determined that in 1918 the Parliament decided to pass the act to close off and partially reclaim the Zuyder Zee. The first important factor was that Lely, the designer of the plan, developed into a formidable statesman and as Minister of Public Works and Water Management repeatedly put the act forward in Parliament. The second factor was that during the First World war the Dutch people became painfully aware of the extent of dependence on foreign countries for their food supply: the wish to produce more home-grown agricultural products was very strong. The third and probably decisive factor was the 1916 storm surge that caused destruction in the area surrounding the Zuyder Zee.

The name Waddenzee (Wadden Sea) is of a relatively recent date. In the second half of the 19th century it was used for the first time and became accepted on 22 September 1932, 


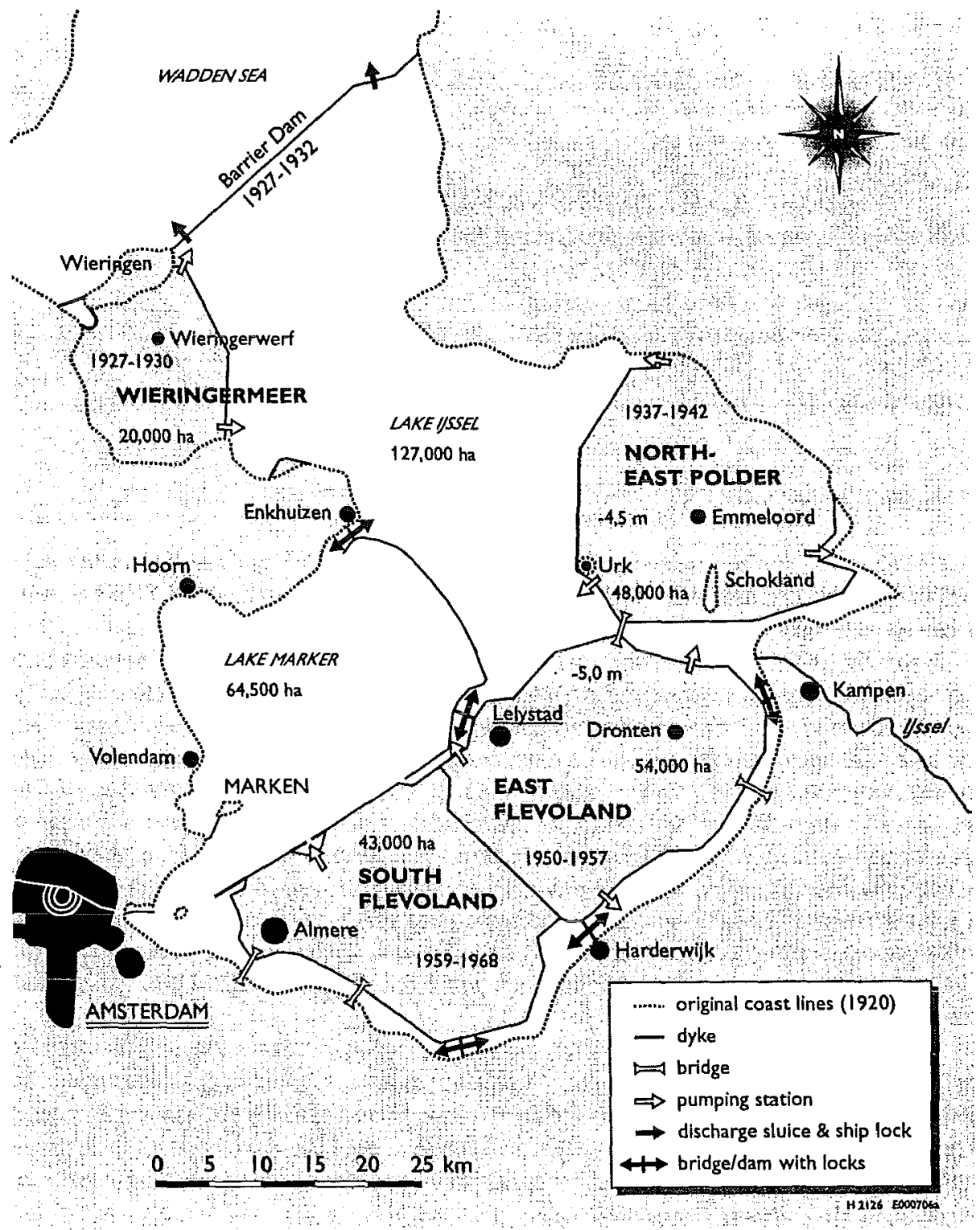

Fig. 1. Situation of the Zuyder Zee Werken (South Sea Project) in The Netherlands. 
Of course, the proposals of 1667 could not be realised then. Incentives, social organisation and a high technological level were essential. It took more than hundred years before these conditions were starting to be met. After the French centralist model the Bataafsche Republic founded in 1798 the Rijks Waterstaat, which promoted the education of anmy and civilian engineers. In 1850, the first polder of the Haarlemmermeer, a two hundred year old plan of Leeghwater, was reclaimed. At that time engineers and civilians started to make plans for reclaiming the Zuyder Zee. Between 1848 and 1886 some 126 plans had been published. The political field investigated, held meetings, even designed laws, but could not reach a decision. Men of name and fame decided it was time for private action and founded the Zuyder Zee Association in 1886. They claimed for subsidies, gave out shares with little success, and finally privately funded the necessary studies. In six years time they were able to produce eight Technical reports, describing the technical feasibility of the closing off and reclamation of the Zuyder Zee.

The leading force behind these Technical reports was Cornelis Lely (1854-1929), who followed civil engineering studies at the Polytechnic School of Delft. Although his initial career was not very successful, his belief in a future career did not die. His ambitions came close to fulfilment when he became an engineer at the Zuyder Zee Association. In the third Technical report he formulated his plans. The five next reports were trivial exercises and before the last one was completed, Lely became Minister of Public works. It took however 27 years, six governments, a storm surge disaster and a World War until on 14 June 1918 his plan was endorsed by law. A State Committee to guide the project, and a special execution agency Zuyder Zeewerken was founded. Three years before the actual closure of the Zuyder Zee by the Afsluitdijk, Lely died. The reclamation of the polders took four decades, and resulted in the largest land reclamation in the world.

\section{Hydraulic Works}

\subsection{ENCLOSURE DIKE/BARRIER DAM}

Prior to the construction of the Enclosure Dike, comprehensive research had to be conducted. One important field of research that had to be developed, concemed that of tidal hydraulics in inlets, because it was realised that closing off the Zuyder Zee would have large repercussions on the tidal motion in the Waddenzee. Specifically, the level of the future storm surges that had to be resisted by the Enclosure Dike and the coast of Holland and Friesland was of course very important. While some, mainly qualitative, physical understanding of tidal motion had been developed, the government decided that this problem deserved thorough research.

This research was to be conducted by the State Committee, established in 1918, and Lorentz was asked to be the chairman. Hendrik A. Lorentz (1853-1928) was a theoreticalphysicist, appointed professor in Leiden in 1878. In 1902 he received the Nobel price for physics together with Zeeman.

Lorentz, bright indeed, had no specific experience in the field of hydraulic engineering. J.Th. Thijsse (1893-1984), a young engineer of the Directorate of the Zuyder Zeewerken, was appointed second secretary. The story goes (Bijker, 1994) that Thijsse accompanied Lorentz on a trip on the Waddenzee to at least experience the sea once. During the greater 


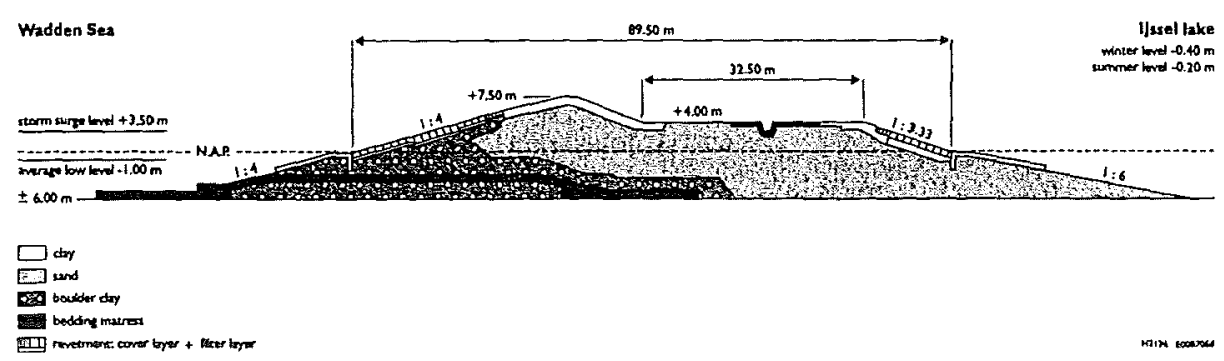

Fig. 2. Cross-section of Enclosure Dike/Barrier Dam.

the east bank of the Amsteldiep where, according to fishermen, 'darned tenacious clay' could be found. This turned out to be boulder clay which was very suitable for dike construction. When processed in large lumps, good boulder clay can withstand velocities up to $4 \mathrm{~m} / \mathrm{s}$ without eroding large quantities of the material. So it could very well be incorporated into the dike bodies and used to seal the closing gaps. On the basis of these priorities, boulder clay has played a mayor role in closing off the Zuyder Zee.

The layers of clay to support the dike body could present problems with regard to settlement and possibly dike slidings as well. For instance, the western section of the dike in the Amsteldiep had to be built on weak layers of clay, 4 to $15 \mathrm{~m}$ thick. Since the problems had not been sufficiently been anticipated here, it had cost quite large amounts of earth and money before a reliable dike body had been built. Later on, the dikes were constructed on top of improved soil that had been created by dredging away the weak clay layers for the greater part and filling up the resultant trench with sand.

The osier need for the fascine mattresses that had to protect the bottom from scouring, were particularly abundant in the Zuid-Holland osier beds. The fascine mattresses were rectangular and consisted of two frames, encasing one or more layers of spread loose twigs. The frames were made up of fascines, which are tied bundles of osier.

The rip-rap, use to reinforce the mattresses, and the facing stones, which served to protect the slopes of the dike against the waves, mainly came from quarries in the Eiffel and the Belgian Ardennes.

The final cross-section of the Enclosure Dike was decided upon in 1925 on the basis of several studies. For the determination of the crest level the criterion was based on the storm surges that had raged in the period 1825-1926. If the Zuyder Zee would have been closed off in that period, a highest level of $3.50 \mathrm{~m}+\mathrm{NAP}$ (Dutch Ordnance Level $\approx$ Mean Sea Level) would have occurred at Den Oever and about $3.75 \mathrm{~m}+$ NAP at the Frisian coast according to the prediction. The storm surge level was raised by the uprush of waves. On the basis of the tests, it was concluded that a slope of 1:4 was most favourable. After having made various calculations, a crest level varying from 6.7-7.4 $\mathrm{m}+\mathrm{NAP}$, depending upon the location, was arrived at. The profile and the structure of the dike body are depicted in Figure 2.

\subsection{THE DIKES AROUND THE IJSSELMEER}

The fact that there was no longer any tidal influence made it much easier to build the dikes around the polders in the IJsselmeer than had been the case for the Enclosure Dike. Deter- 


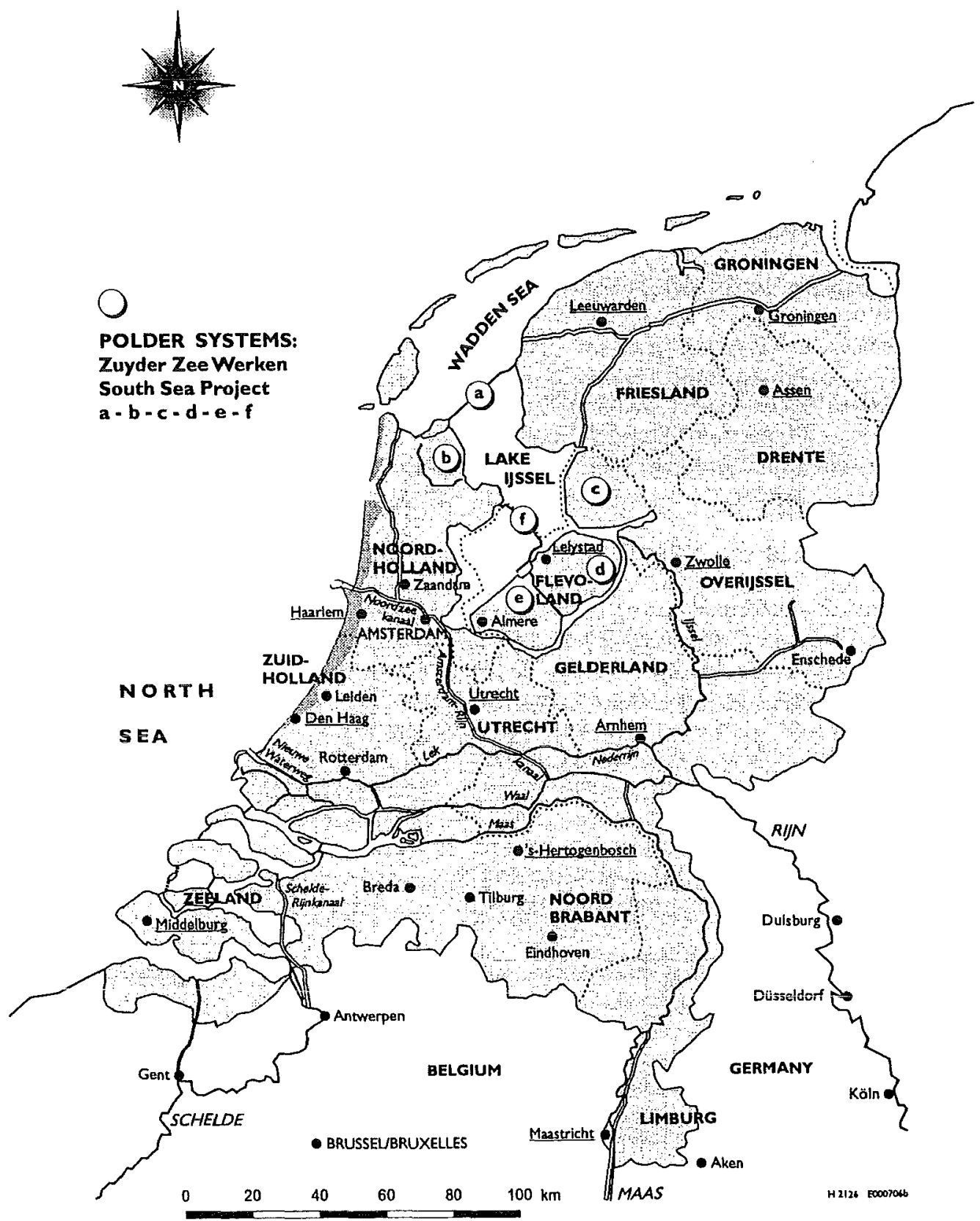

Fig. 3. Zuyder Zee Werken/South Sea Project. a - Barrier Dam; b - Wieringermeer Polder; c - Northeast Polder; d-East Flevo Polder; e - South Flevo Polder; f - Dike Enkhuizen-Lelystad. 
lakes fulfil an important role in the regulation and control of the ground water levels in the adjacent hinterland. The general principle of a polder system is depicted in Figure 4.

\section{Impact of the Zuyder Zee Enclosure Dike on the Waddenzee}

Through the work of the State Committee Lorentz, the impact of the construction of the Enclosure Dike, the Afsluitdijk, on the tidal velocities in the Waddenzee inlets was anticipated. However, the consequences in terms of geomorphology of the Waddenzee tidal basins could not be predicted. Of the tidal basins the basinal area of the Texel Inlet has been affected most, and it is yet not well-known whether this basin has reached a new dynamic equilibrium state.

The Texel Inlet basinal area has been reduced considerably, which implies that the new basin created a sand and silt deficit. At the same time, however, the increased tidal velocities in the inlet are indicating an increase in tidal prism. The consequences of these changes are complex. The increased tidal prism can be expected to imply a sand deficit for the ebb-tidal delta as well. Together with the sediment deficit of the basin this implied an increase in the sand demand from the coasts adjacent to the Texel Inlet. Reconstruction of the observations has shown (Stive et al., 1990) that the coasts of Texel and the north of North-Holland have been supplying the sediment required, but not in the amounts that the Texel Inlet basin required. As a consequence the ebb-tidal delta has played the role of sediment source in this complex interacting system, which has been leading to a structural decay of the ebb-tidal volume. This process may be expected to be ending at some stage, but our capabilities to predict this are rather limited and only slowly developing (Stive et al., 1996).

\section{Discussion and Conclusion}

In the 20th century, the history of water management and land reclamation in the Netherlands is dominated by two large-scale projects: the Zuyder Zee project and the Delta project. The Delta Project was an answer to the 1953 storm surge disaster in the Southwest of The Netherlands. It consisted of the complete or partial closure of the various estuaries by a series of dams and storm surge barriers, drastically shortening the coastline (see also Chapter 12 by Schiereck). Both projects have drastically changed the topography and the environment of the Netherlands over a surface of around 1,000,000 hectares: more than a quarter of the country. The decisions of 1918 and 1958 to carry out these projects were made almost unanimously; the decisive factor was formed by the attacks of the traditional enemy and friend of the Netherlands: the sea. Now, enough time has elapsed to conclude that both projects have been a success in resolving the main issues of protection against flooding and of management of water. On the other hand, now that these issues have been resolved, there is a growing awareness that the projects have resulted in a loss of natural values and of the naturals system's resilience. The coming decades are expected to be devoted to answering the societal and political wish towards restoring and where possible strengthening of the natural situation, which is expected to enhance the natural system's resilience. 


\section{Acknowledgements}

Important parts of this text describing the history of the project and the construction of the enclosing dam are based on the comprehensive documentation on the Zuyder Zee works in the book "Man-made lowlands: a history of water management and land reclamation in the Netherlands", Ed: G.P. van de Ven, 1993. Other sources of importance were Bijker (1996) and Waterman (1997).

\section{References}

Beets, D.J., Van der Valk, L., and Stive, M.J.F., 1992. Holocene evolution of the coast of Holland, Marine Geology, $103,423-443$

Bijker, E.W.1996. History and heritage in coastal engineering in the Netherlands. In: History and Heritage of Coastal Engineering, Ed. N.C. Kraus, ASCE, pp. 390-412.

Staatscommissie Lorentz, 1926. Report in Dutch, Staatsdrukkerij.

Stive, M.J.F., Roelvink, J.A. and De Vriend, H.J., 1990. Large-scale coastal evolution concept, Proc. 22nd Int. Conf. on Coastal Eng., ASCE, New York.

Stive, M.J.F., Capobianco, M., Wang, Z.B., Ruol, P. and Buijsman, M., 1996. Morphodynamics of a tidal lagoon and the adjacent coast, 8th International Conference on Physics of Estuaries and Coastal Zones, The Hague, The Netherlands, September 9-12, 1996

Thijsse, J.Th., 1922. Berechnung von Gezeitenwellen mit betrachtlicher Reibung. Vortrage aus dem Gebiet der Hydro- und Aerodynamik, Innsbruck. Springer, Berlin.

Thijsse, J.Th., 1933. L'influence de la fermeture du Zuyderzee sur le regime des marees le long de cotes Neerlandaises. Bulletin de l'Association permanente des congres de navigation, No. 15.

Waterman, R.E., 1997. Large-scale coastal land reclamations, Proceedings of Cosu 97 - Coastal Ocean Space Utilisation. 